\title{
Zerumbone suppresses EGF-induced CD44 expression through the inhibition of STAT3 in breast cancer cells
}

\author{
SANGMIN KIM* ${ }^{*}$, WON HO KIL ${ }^{*}$, JEONGMIN LEE, SOO-JIN OH, JEONGHUN HAN, MYEONGJIN JEON, \\ TAEWOO JUNG, SE KYUNG LEE, SOO YOUN BAE, HYUN CHUL LEE, JUN HO LEE, \\ HA WOO YI, SEOK WON KIM, SEOK JIN NAM and JEONG EON LEE \\ Department of Surgery, Samsung Medical Center, Sungkyunkwan University School of Medicine, \\ Gangnam-gu, Seoul 135-710, Republic of Korea
}

Received May 28, 2014; Accepted August 29, 2014

DOI: $10.3892 /$ or.2014.3514

\begin{abstract}
Expression of the CD44 gene is upregulated in breast cancer cells and is correlated with patient survival. Aberrant CD44 expression promotes tumor progression and metastasis. In the present study, we investigated the role of zerumbone (ZER) on regulatory mechanisms of CD44 expression in breast cancer cells. Our results showed that CD44 expression was significantly increased by epidermal growth factor receptor (EGFR) ligands in SKBR3 breast cancer cells. In contrast, EGF-induced CD44 expression was decreased by a MEK1/2 inhibitor, UO126, or STAT3 inhibitor, STAT3 VI, respectively. Notably, ZER downregulated the basal level of CD44 expression in $\mathrm{CD}_{4} 4^{+}$breast cancer cells. In addition, the induction of CD44 expression by EGFR ligands, EGF or TGF- $\alpha$, was markedly decreased by ZER treatment. Finally, we investigated the inhibitory mechanism of ZER on EGF-induced CD44 expression. Our results showed that EGF-induced phosphorylation of STAT3 was completely suppressed by ZER. Collectively, ZER suppressed EGF-induced CD44 expression through inhibition of the STAT3 pathway. Therefore, we suggested that ZER may act as a promising therapeutic drug for the treatment of breast cancer.
\end{abstract}

\section{Introduction}

Breast cancer is a highly complex disease with large interand intra-tumoral heterogeneity; the basal-like molecular subtype of breast cancer has the poorest clinical outcome (1). Epidermal growth factor receptor (EGFR) is frequently overexpressed in triple-negative breast cancer (TNBC) and

Correspondence to: Professor Jeong Eon Lee or Professor Seok Jin Nam, Department of Surgery, Samsung Medical Center, Sungkyunkwan University School of Medicine, 50 Irwon-dong, Gangnam-gu, Seoul 135-710, Republic of Korea

E-mail: paojlus@hanmail.net

E-mail: sjnam@skku.edu

*Contributed equally

Key words: zerumbone, CD44, STAT3, ALDH, breast cancer inflammatory breast cancer (IBC) in comparison with other subtypes of breast cancer (2). Highly-expressed EGFR is associated with a number of characteristics including large tumor size, poor differentiation and poor clinical outcome in a variety of cancer cells, including breast and lung cancer cells (3). In addition, elevated EGFR and CK5/14 expression was associated with the status of $\mathrm{CD} 44^{+} / \mathrm{CD} 24^{-}$in basal-like subtypes of breast cancer (4). A population of CD $44^{+} / \mathrm{CD} 24^{-/ \text {low }}$ tumor cells has also been associated with the aggressive basallike breast cancer (4). In a recent study, we also reported that CD44 expression is regulated through EGFR/ERK-dependent pathways in breast cancer cells (5).

Hyaluronan (HA) is a component of the extracellular matrix and binds to its predominant cell-surface receptor CD44 (6,7). Aberrant expression of HA correlates with poorly differentiated tumors, auxiliary lymph node status and short overall survival time in breast cancer (8). HA/CD44 complex promotes multiple signaling pathways that influence many tumor cell activities, including abnormal growth, migration and invasion (9-11). The standard form of CD44 is generally ubiquitously expressed on epithelial cells and lymphocytes (7). The CD44 gene is composed of at least 20 exons that tissuespecific multiple variant isoforms (CD44v1-v10) is produced by alternate mRNA splicing (12). Indeed, induction of CD44s alone affected the growth characteristics of non-invasive luminal breast cancer cells including the induction of cell proliferation, cell migration and cell invasion in vitro (13). In addition, overexpression of CD44v3 isoforms promotes breast tumor cell migration and the attachment of VEGF to the heparin sulfate sites on CD44v3 is responsible for the onset of breast tumor-associated growth (14).

Zerumbone [2,6,9,9-tetramethylcycloundeca-2,6,10-trien1-one; (ZER)], a monocyclic sesquiterpene derived from a Southeast Asian ginger, is often used as an anti-inflammatory and antioxidant agent (15-17). ZER has contributed to antitumor activities in a variety of cancers, such as colon and gastric cancer (17). In addition, ZER triggers apoptosis through modulation of the $\mathrm{Bax} / \mathrm{Bcl}-2$ ratio in $\mathrm{HepG} 2$ liver cancer cells (17). Downregulation of CXCR4 expression by ZER suppressed CXCL12-induced cell invasion through the inhibition of $\mathrm{NF}-\kappa \mathrm{B}$ activity in breast and pancreatic cancer cells (18). Despite these studies, however, the regulatory 
mechanisms of ZER on EGFR signaling pathways are not yet fully understood.

In the present study, we examined the role of ZER on the regulatory mechanism of EGF-induced CD44 expression in breast cancer cells. In particular, we found that ZER has an inhibitory effect on the EGF/STAT3 signaling pathway in breast cancer cells. EGF-induced CD44 expression also was regulated by the STAT3 dependent pathway.

\section{Materials and methods}

Reagents and cell culture. Dulbecco's modified Eagle's medium (DMEM), RPMI-1640 and the antibiotics were purchased from Life Technologies (Rockville, MD, USA). Fetal bovine serum (FBS) was purchased from HyClone (Logan, UT, USA). UO126 and LY294002 were purchased from Tocris Bioscience (Ellisville, MO, USA). Mouse monoclonal anti-CD44 antibody was purchased from Cell Signaling Technology (Beverly, MA, USA). The secondary HRP-conjugated antibodies, as well as the mouse monoclonal anti- $\beta$-actin antibody, were purchased from Santa Cruz Biotechnology, Inc. (Santa Cruz, CA, USA). Rabbit monoclonal phospho- and total-Akt, STAT3 and Erk1/2 antibodies were purchased from Epitomics (Burlingame, CA, USA). ZER was a gift from Dr Murakami (Kyoto University, Kyoto, Japan). EGF and TGF- $\alpha$ were purchased from R\&D Systems (Minneapolis, MN, USA). ALDEFluor ${ }^{\mathrm{TM}}$ kit was purchased from Stemcell Technologies (Durham, NC, USA).

SKBR3 and MDA-MB468 human breast cancer cells were grown in a humidified atmosphere of $95 \%$ air and $5 \% \mathrm{CO}_{2}$ at $37^{\circ} \mathrm{C}$ in RPMI-1640 supplemented with $10 \%$ FBS, $2 \mathrm{mM}$ glutamine, $100 \mathrm{IU} / \mathrm{ml}$ penicillin and $100 \mu \mathrm{g} / \mathrm{ml}$ streptomycin.

ZER and specific inhibitor treatment. Cells were maintained in culture medium without FBS for $24 \mathrm{~h}$. Then, the culture media was replaced with fresh media without FBS. Cells were pretreated with 5 or $10 \mu \mathrm{M}$ concentrations of ZER for $16 \mathrm{~h}$ prior to EGF treatment and were then treated with $50 \mathrm{ng} / \mathrm{ml}$ EGF for $24 \mathrm{~h}$. In experiments involving specific inhibitors, such as UO126, LY294002 and STAT3 inhibitor, each cell was pretreated with specific inhibitors for $30 \mathrm{~min}$ prior to treatment with EGF and they were then treated with EGF for $24 \mathrm{~h}$.

Western blotting. The cell culture media (supernatants) and cell lysates were used in the immunoblot analysis for CD44, EGFR, STAT3, Erk, Akt and $\beta$-actin. Cells were lysed on ice for $30 \mathrm{~min}$. The cell lysate was collected into microtubes and samples were centrifuged for $15 \mathrm{~min}$ at $12,000 \mathrm{rpm}$ at $4^{\circ} \mathrm{C}$. Supernatants were collected and the protein concentrations were measured using the Bio-Rad Protein Assay kit (Hercules, CA, USA). The proteins were boiled for $5 \mathrm{~min}$ in Laemmli sample buffer and they were then electrophoresed in $10 \%$ SDS-PAGE gels, respectively. The separated proteins were transferred to PVDF membranes and the membranes were then blocked with $10 \%$ skim milk in TBS with $0.01 \%$ Tween-20 for $15 \mathrm{~min}$. The blots were incubated with anti-CD44, EGFR, STAT3, ERK, AKT and $\beta$-actin antibodies in $1 \%$ TBS/T buffer (0.01\% Tween-20 in TBS) at $4^{\circ} \mathrm{C}$ overnight. The blots were washed 3 times in TBS with $0.01 \%$ Tween-20 and they were subsequently incubated with anti-rabbit peroxidase-conjugated antibody (1/2,000 dilution) in TBS/T buffer. After $1 \mathrm{~h}$ incubation at room temperature (RT), the blots were washed 3 times and ECL Prime reagents were used for development.

Real-time PCR. Total RNA was extracted from the cells using the TRIzol reagent (Invitrogen, Carlsbad, CA, USA), according to the manufacturer's instructions. Isolated RNA samples were then used for RT-PCR. Samples $(1 \mu \mathrm{g}$ of total RNA) were reverse-transcribed into cDNA in $20 \mu \mathrm{l}$ reaction volumes using a first-strand cDNA synthesis kit for RT-PCR, according to the manufacturer's instructions (MBI Fermentas, Hanover, MD, USA).

The gene expression was quantified by real-time PCR using a SensiMix SYBR kit (Bioline Ltd., London, UK) and $100 \mathrm{ng}$ of cDNA/reaction. The sequences of the primer sets used for this analysis were: human CD44s (forward, 5'-CCA AGA TGA TCA GCC ATT CTG G-3' and reverse, 5'-AAG ACA TCT ACC CCA GCA AC-3') and GAPDH as an internal control (forward, 5'-ATT GTT GCC ATC AAT GAC CC-3' and reverse, 5'-AGT AGA GGC AGG GAT GAT GT-3'). An annealing temperature of $60^{\circ} \mathrm{C}$ was used for all primers. PCRs were performed in a standard 384-well plate format with an ABI 7900HT Real-Time PCR detection system. For data analysis, the raw threshold cycle $\left(\mathrm{C}_{\mathrm{T}}\right)$ value was first normalized to the housekeeping gene for each sample to get the $\Delta \mathrm{C}_{\mathrm{T}}$. The normalized $\Delta \mathrm{C}_{\mathrm{T}}$ was then calibrated to the control cell samples to get the $\Delta \Delta \mathrm{C}_{\mathrm{T}}$.

Cell viability. To confirm ZER toxicity, we used treatment with the indicated concentrations of ZER and total cell numbers were evaluated by Quick Cell Proliferation Assay kit II (BioVision, Mountain View, CA, USA) according to the manufacturer's protocol. Briefly, CD44-positive cells, MDA-MB468 and SKBR3 human breast cancer cells $\left(5 \times 10^{4} /\right.$ well) were grown in a 96-well plate in $100 \mu \mathrm{l} /$ well of culture media in the absence or presence of ZER. After incubating the cells for $24 \mathrm{~h}, 10 \mu \mathrm{l}$ WST reagent was added to each well. Viable cells were quantified photometrically at $480 \mathrm{~nm}$.

ALDEFLUOR assay. The ALDEFLUOR kit (Stem Cell Technologies, Grenoble, France) was used for the immunofluorescent detection of intracellular ALDH enzyme activity, using a FACS-vantage (Becton-Dickinson, San Diego, CA, USA), according to the manufacturer's instructions. Briefly, cells were incubated in ALDEFLUOR assay buffer containing ALDH substrate ( $1 \mathrm{mM} / 1$ per 13,106 cells). In each experiment, a sample of cells was incubated, under identical conditions, with $50 \mathrm{mM} / 1$ of diethylaminobenzaldehyde, a specific ALDH inhibitor, as a negative control.

Statistical analysis. Statistical significance was determined using the Student's t-test. Data are presented as means \pm SEM. All quoted P-values are two-tailed and P-values $<0.05$ were considered to indicate statistically significant differences. Microsoft Excel was used for statistical analyses.

\section{Results}

EGF augments the basal level of CD44 $\mathrm{mRNA}$ and protein expression in the SKBR3 breast cancer cells. In the present 


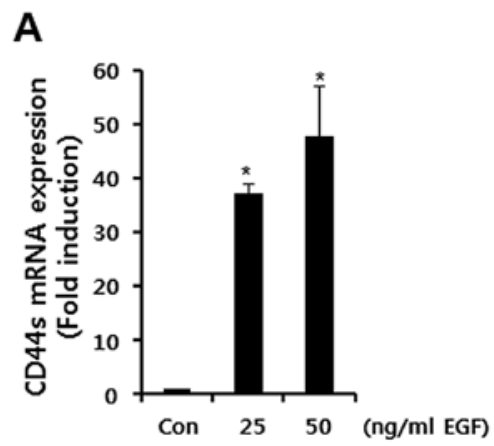

B

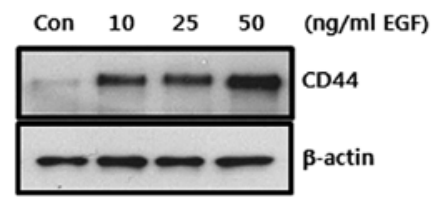

C

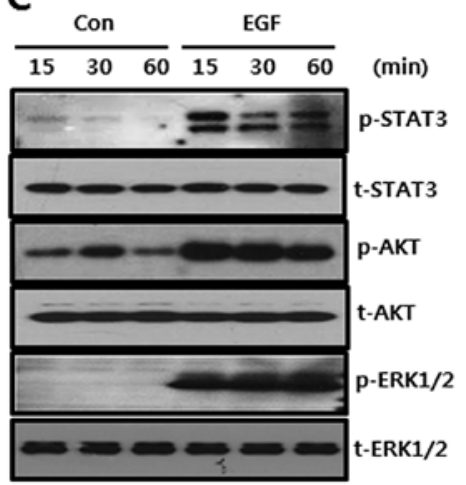

Figure 1. EGF augments the basal level of CD44 mRNA and protein expression in the SKBR3 breast cancer cells. (A and B) After serum-starvation for $24 \mathrm{~h}$, SKBR3 cells were treated with EGF at the indicated doses for $24 \mathrm{~h}$. The levels of CD44 mRNA (A) and protein (B) expression were analyzed by real-time PCR and western blotting, respectively. (C) After serumstarvation for $24 \mathrm{~h}$, SKBR3 cells were treated with $50 \mathrm{ng} / \mathrm{ml}$ EGF for the indicated times. The phosphorylation levels of EGFR, STAT3, Akt and Erk were analyzed by western blotting. The results are representative of 3 independent experiments. The values shown are the means \pm SEM. ${ }^{*} \mathrm{P}<0.05$ vs. control. Con, control.

study, we sought to verify the effect of EGF on CD44 mRNA and protein expression. As a result, we treated the CD44 with EGF for $24 \mathrm{~h}$ at the indicated concentrations. As shown in Fig. 1A and B, the levels of CD44 mRNA and protein expression were increased by EGF treatment in a dose-dependent manner. After $50 \mathrm{ng} / \mathrm{ml}$ EGF treatment, the levels of the CD44 mRNA expression were significantly increased to 48.1-fold that of the control level (Fig. 1A).

We also examined EGF-induced the phosphorylation of STAT-3, ERK and AKT which are the downstream signaling molecules of EGF. The levels of STAT-3, ERK and AKT phosphorylation were significantly increased by $50 \mathrm{ng} / \mathrm{ml} \mathrm{EGF}$ treatment in SKBR3 breast cancer cells (Fig. 1C).

EGF ligand-induced CD44 $\mathrm{mRNA}$ and protein expression levels are suppressed by MEK1/2 or STAT-3 inhibitors in SKBR3 breast cancer cells. To verify the regulatory mecha-
A
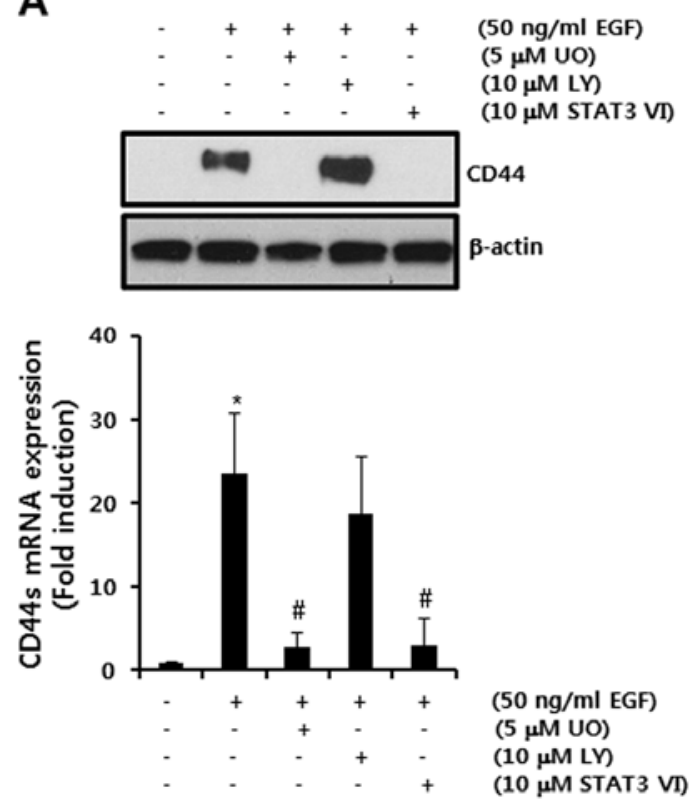

B
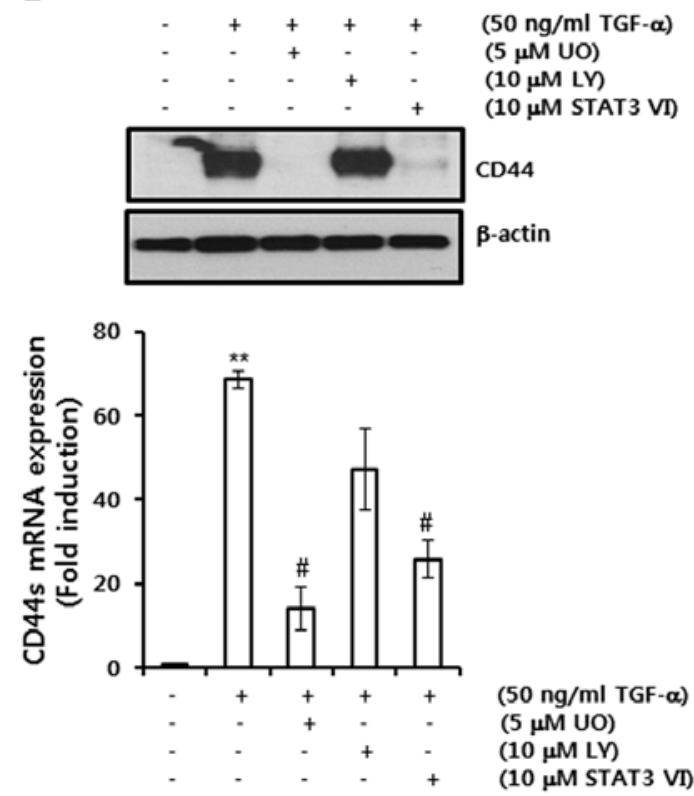

Figure 2. EGF ligand-induced CD44 mRNA and protein expression levels are suppressed by a MEK1/2 inhibitor or STAT3 inhibitor, respectively. (A and B) After serum-starvation for $24 \mathrm{~h}$, SKBR3 cells were pretreated with $10 \mu \mathrm{M} \mathrm{UO}, \mathrm{LY}$ and STAT3 VI, respectively, for $30 \mathrm{~min}$ and were then treated with $50 \mathrm{ng} / \mathrm{ml} \mathrm{EGF} \mathrm{(A)} \mathrm{or} \mathrm{TGF-} \alpha$ (B) for $24 \mathrm{~h}$, respectively. The levels of CD44 and $\beta$-actin protein expression were analyzed by western blotting. The levels of CD44s mRNA were analyzed by real-time PCR. The results are representative of 3 independent experiments. The values shown are the means \pm SEM. ${ }^{*} \mathrm{P}<0.05,{ }^{* *} \mathrm{P}<0.01$ vs. control. ${ }^{*} \mathrm{P}<0.05$ vs. EGF-treated cells. Con, control; UO, UO126; LY, LY294002; STAT3 VI, STAT3 inhibitor VI.

nism of EGF-induced CD44 mRNA and protein expression, we pretreated cells with the specific inhibitors, including UO, a MEK1/2 inhibitor; LY, a PI3K inhibitor; and STAT3 IV, a STAT-3 inhibitor, respectively, for $30 \mathrm{~min}$ prior to $50 \mathrm{ng} / \mathrm{ml}$ EGF treatment. Our results showed that EGF-induced CD44 protein and mRNA expression was decreased by UO or STAT-3 IV inhibitors, respectively (Fig. 2A). 


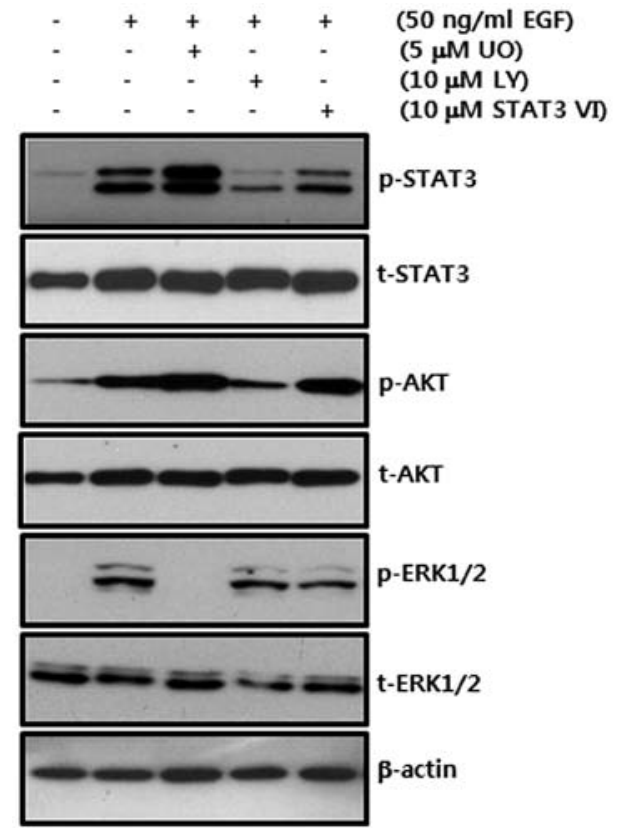

Figure 3. Effect of specific inhibitors on EGF-induced phosphorylation of STAT3, AKT and ERK in SKBR3 breast cancer cells. After serum-starvation for $24 \mathrm{~h}$, SKBR 3 cells were pretreated with $10 \mu \mathrm{M}$ UO, LY and STAT3 VI, respectively, for $30 \mathrm{~min}$. They were then treated with $50 \mathrm{ng} / \mathrm{ml}$ EGF for $30 \mathrm{~min}$. The levels of STAT3, AKT and ERK phosphorylation by EGF were analyzed by western blotting. The results are representative of 3 independent experiments. Con, control; UO, UO126; LY, LY294002; STAT3 VI, STAT3 inhibitor VI.

The levels of CD44 mRNA expression were increased to 23.4 -fold of the control level by $50 \mathrm{ng} / \mathrm{ml}$ EGF treatment (Fig. 2A). On the other hand, EGF-induced CD44 mRNA and protein expression was significantly decreased by 3.8 - and 4.2 -fold of the control level by $10 \mu \mathrm{M} \mathrm{UO}$ and $10 \mu \mathrm{M}$ STAT3 VI treatment, respectively (Fig. 2A). In addition, we confirmed the effect of another EGFR ligand, TGF- $\alpha$, on CD44 mRNA and protein. As expected, TGF- $\alpha$-induced CD44 protein and mRNA expression was also decreased by $10 \mu \mathrm{M}$ UO and $10 \mu$ M STAT3 VI treatment, respectively (Fig. 2B).

Next, we investigated the inhibitory effect of specific inhibitors through the phosphorylation of signaling molecules. Each inhibitor specifically decreased the phosphorylation of STAT-3, AKT and ERK1/2 (Fig. 3). These results demonstrate that EGF-induced CD44 expression is regulated through the MEK/ERK and JAK/STAT3 dependent pathways in breast cancer cells.

The basal level of CD44 is decreased by ZER in CD44-positive breast cancer cells. In order to verify the effect of ZER on CD44 expression, we treated CD44-positive breast cancer cells with ZER. The chemical structure of ZER is depicted in Fig. 4A. Cell viabilities were not altered by ZER treatment in CD44-positive breast cancer cells (Fig. 4B). However, we found that the basal level of CD44 mRNA expression was decreased by ZER treatment in MDA-MB468 and SKBR3 breast cancer cells (Fig. 4C). The level of CD44 mRNA expression was decreased by 0.69 -fold (in MDA-MB468 cells) and 0.68 -fold (in SKBR3 cells) of the control level at $10 \mu \mathrm{M}$ ZER, respectively (Fig. 4C).
A<smiles>CC(=CCC(C)(C)C)CCC(C)C</smiles>

B
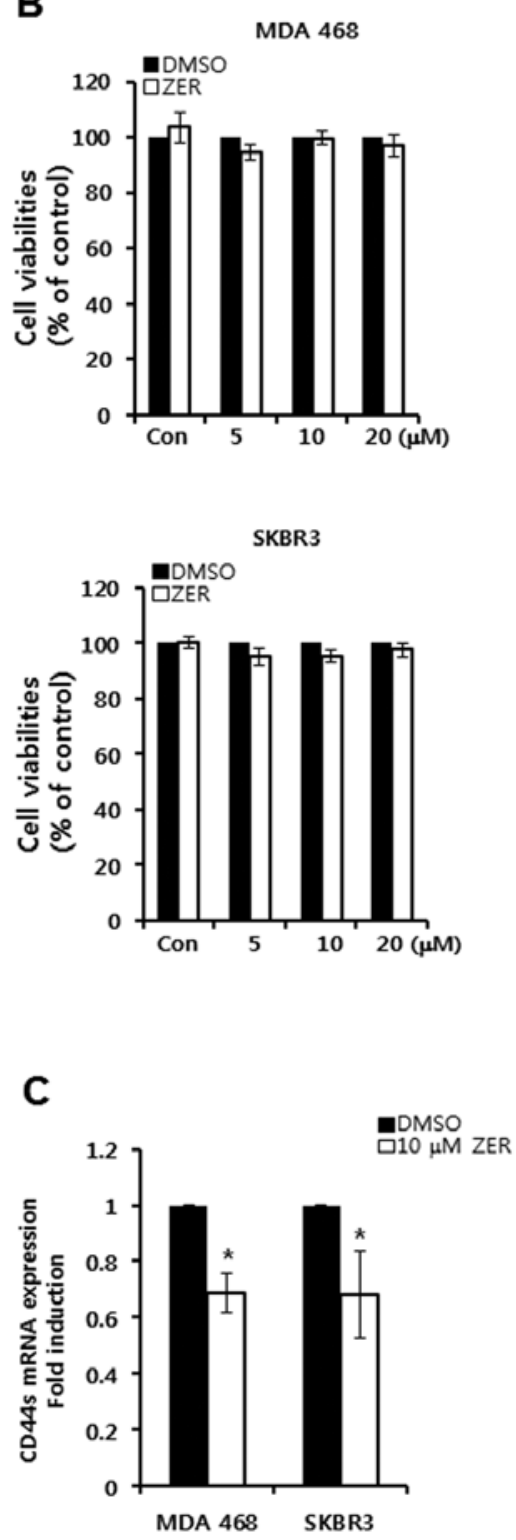

Figure 4. Basal level of CD44 is decreased by ZER in CD44-positive breast cancer cells. (A) The chemical structure of ZER. (B) After serum-starvation for $24 \mathrm{~h}$, SKBR3 and MDA-MB468 cells were treated with $10 \mu \mathrm{M}$ ZER for 24 h. Cell viabilities were analyzed by Quick Cell Proliferation Assay. (C) The level of CD44 mRNA was analyzed by real-time PCR. The results are representative of 3 independent experiments. The values shown are the means \pm SEM. ${ }^{*} \mathrm{P}<0.05$ vs. control. Con, control; ZER, zerumbone.

EGF ligand-induced CD44 $m R N A$ and protein expression levels are suppressed by ZER. To investigate the effect of ZER on EGF-induced CD44 expression, we pretreated cells with 
A

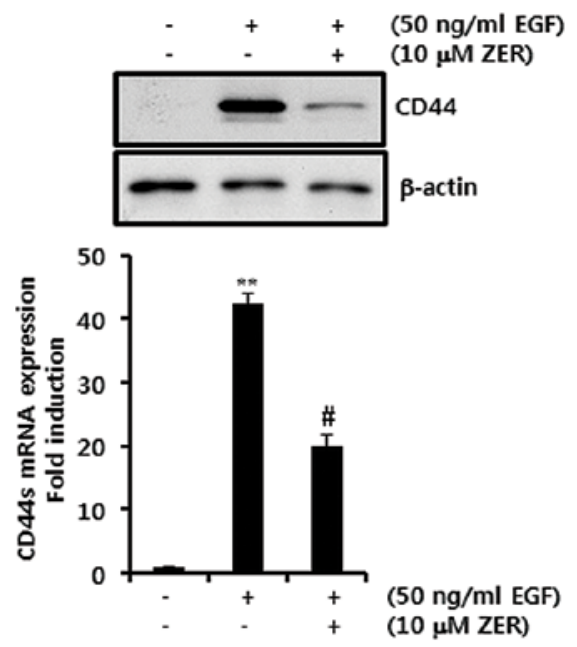

B
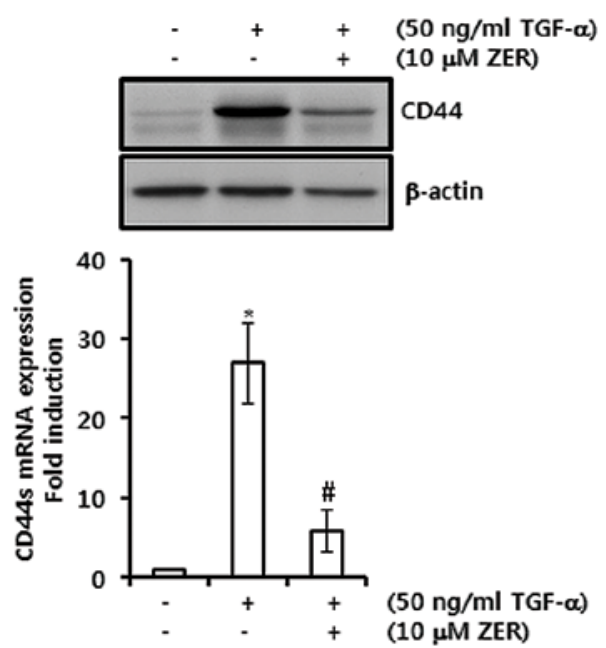

C
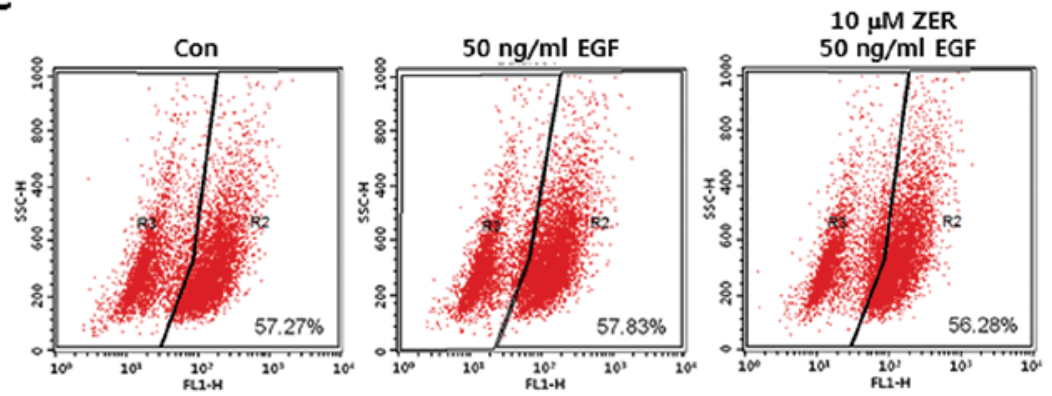

Figure 5. EGF ligand-induced CD44 mRNA and protein expression levels are suppressed by ZER in SKBR3 breast cancer cells. (A-C) After serum-starvation for $24 \mathrm{~h}$, SKBR3 cells were pretreated with $10 \mu \mathrm{M}$ ZER for $16 \mathrm{~h}$, and were then treated with $50 \mathrm{ng} / \mathrm{ml}$ EGF (A) or TGF- $\alpha$ (B) for $24 \mathrm{~h}$, respectively. The levels of CD44 and $\beta$-actin protein expression were analyzed by western blotting. The levels of CD44s mRNA were analyzed by real-time PCR. (C) ALDH enzyme activity was detected as described in Materials and methods. The results are representative of 3 independent experiments. The values shown are the means \pm SEM. ${ }^{*} \mathrm{P}<0.05,{ }^{* * *} \mathrm{P}<0.01$ vs. control. ${ }^{~} \mathrm{P}<0.05$ vs. EGF-treated cells. Con, control; UO, UO126; LY, LY294002; STAT3 VI, STAT3 inhibitor VI; ZER, zerumbone.

$10 \mu \mathrm{M}$ ZER for $16 \mathrm{~h}$ prior to $50 \mathrm{ng} / \mathrm{ml}$ EGF treatment. Our results showed that the levels of CD44 protein and mRNA expression by EGF were significantly decreased after ZER treatment (Fig. 5A). The levels of EGF-induced CD44 mRNA expression were suppressed by 19.8 -fold of control level by $10 \mu \mathrm{M}$ ZER treatment (Fig. 5A). Under the same conditions, we investigated the effect of ZER on TGF- $\alpha$-induced CD44 protein and mRNA expression. As expected, our results showed that the induction of CD44 protein and mRNA expression in response to TGF- $\alpha$ was decreased by ZER treatment (Fig. 5B). The levels of TGF- $\alpha$-induced CD44 mRNA expression were decreased by 5.9-fold of control level by $10 \mu \mathrm{M}$ ZER treatment (Fig. 5B).

Next, we examined the correlation between CD44 expression and ALDH enzyme activity. As shown in Fig. 5C, the $\mathrm{ALDH}^{+}$population was not changed; however, CD44 expression was altered by EGF and/or ZER treatment. Therefore, we demonstrated that ZER may act as a promising inhibitor of the EGF signaling pathway in breast cancer cells.

EGF-induced phosphorylation of STAT3 is suppressed by ZER treatment in SKBR3 breast cancer cells. We investigated whether ZER regulates the phosphorylation of EGF/EGFR downstream signaling molecules in breast cancer cells. We pretreated cells with $10 \mu \mathrm{M}$ ZER for $16 \mathrm{~h}$ and then $50 \mathrm{ng} / \mathrm{ml}$ EGF for $30 \mathrm{~min}$. We observed that EGF-induced STAT-3 phosphorylation was markedly decreased by ZER but not ERK1/2 and AKT phosphorylation (Fig. 6). Therefore, we demonstrated that ZER may suppress EGF-induced CD44 expression through the inhibition of the STAT-3 dependent pathway in breast cancer cells.

\section{Discussion}

The EGFR and its ligands activate several mechanisms underlying tumor progression, including cell proliferation, survival and tumor invasion $(19,20)$. In particular, aberrant EGFR activation by frequent overexpression or constitutive activation can promote tumor processes including angiogenesis and metastasis; it is also associated with poor prognosis in many human malignancies (21). The major signaling pathways activated by EGFR are mediated by different intracellular signaling cascades, including the phosphatidylinositol 3-kinase (PI3K)/Akt, the Raf/MEK/ERK and the signal transducer and activator of transcription (STAT) pathways $(22,23)$. In accordance with these previous studies, our results showed that the 


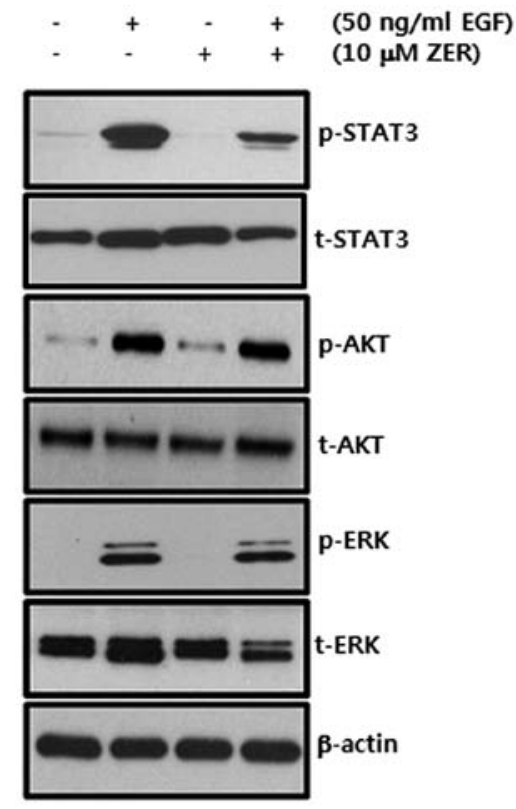

Figure 6. EGF-induced phosphorylation of STAT3 is suppressed by ZER treatment in SKBR3 breast cancer cells. After serum-starvation for $24 \mathrm{~h}$, SKBR 3 cells were pretreated with $10 \mu \mathrm{M}$ ZER for $16 \mathrm{~h}$, and were then treated with $50 \mathrm{ng} / \mathrm{ml} \mathrm{EGF}$ for $30 \mathrm{~min}$. The levels of phospho- and total-STAT3, Akt and ERK were analyzed by western blotting. The results are representative of 3 independent experiments. ZER, zerumbone.

phosphorylation of STAT3, Akt and ERK were significantly increased by EGF treatment in breast cancer cells. Although we did not observe data, MMP-9 expression, which is a drive gene of tumor invasion and metastasis, also markedly increased under the same conditions.

The EGF/EGFR signaling pathway stimulates cellular interactions with ECM components, HA in particular, by upregulation of CD44 expression in murine NR6 cells $(24,25)$. Overexpression of CD44 is involved in tumor progression, including induction of tumor cell motility and enhancement of tumor growth and metastasis (26). The promoter region of CD44 contains AP-1 binding sites and EGF-induced AP-1 transcription activity mediates cell invasion through induction of CD44 (27). We also reported that the transcriptional activity of CD44 is regulated by an EGFR/ERK-dependent pathway in breast cancer cells (5). Consistent with these reports, our results showed that EGFR ligands, EGF and TGF- $\alpha$ augment the level of CD44 expression in a dose-dependent manner. EGF-induced CD44 expression was also decreased by a MEK1/2 specific inhibitor, UO126. In particular, EGFR ligand-induced CD44 expression was markedly decreased by STAT-3 specific inhibitor, STAT3 VI. Therefore, we demonstrated that the transcriptional activity of STAT-3 plays a key role in the induction of CD44 in breast cancer cells.

Zerumbone (ZER), a sesquiterpene, is an anti-inflammatory agent (17); it has apoptotic effects against a wide variety of tumor cells, including colon cancer and leukemia cells $(17,28)$. In addition, ZER suppresses CXCL12-mediated invasion of breast and pancreatic tumor cells through the downregulation of CXCR4 (18). The suppression of NF- $\kappa \mathrm{B}$ activity by ZER inhibits the secretion of angiogenic factors, such as VEGF and IL-8, in pancreatic cancer cells (29). We also found that ZER abolishes the basal levels of CD44 mRNA expression in
CD44-positive breast cancer cells. Furthermore, ZER significantly decreased EGFR ligand-induced CD44 expression in SKBR3 breast cancer cells. In the present study, we found for the first time that ZER significantly suppresses EGF-induced phosphorylation of STAT3. Therefore, we demonstrated that ZER inhibits EGFR ligand-induced CD44 expression through the suppression of STAT3 activity.

To date, a variety of cancer stem/progenitor cells from different tissues, including breast and colorectal cancer, have illustrated highly expressed CD44 molecules (30,31). In a recent study, Herishanu et al reported that anti-CD44 mAbs can also inhibit proliferation and induce apoptosis of leukemia stem cells (32). However, our results showed that the reduction of CD44 expression by ZER treatment did not lead to the alteration of $\mathrm{ALDH}^{+}$population. Therefore, we demonstrated that ZER is not directly involved with the stemness of breast cancer cells.

In conclusion, we clearly demonstrated the regulatory mechanism of ZER on EGF-induced CD44 expression in breast cancer cells. Elevated STAT3 activity in response to EGF ligands, including EGF and TGF- $\alpha$, directly regulated the levels of CD44 expression. On the other hand, EGF-induced CD44 expression was suppressed by a STAT3 specific inhibitor, STAT3 VI. In particular, EGF-induced STAT3 phosphorylation and CD44 expression were significantly decreased by ZER treatment. Based on these findings, we suggest that ZER may be a promising therapeutic drug for the treatment of breast cancer through the blockage of the EGFR signaling pathway.

\section{Acknowledgements}

This study was supported by a Korea Research Foundation Grant funded by the Korean Government(NRF-2012R1A1B4000493), and by a Samsung Biomedical Research Institute grant (SMX1131701), and by a grant of the Korea Health Technology R\&D Project through the Korea Health Industry Development Institute (KHIDI), funded by the Ministry of Health and Welfare, Republic of Korea (HI09C1552).

\section{References}

1. Minn AJ, Gupta GP, Siegel PM, Bos PD, Shu W, Giri DD Viale A, Olshen AB, Gerald WL and Massagué J: Genes that mediate breast cancer metastasis to lung. Nature 436: 518-524, 2005.

2. Rakha EA, El-Sayed ME, Green AR, Lee AH, Robertson JF and Ellis IO: Prognostic markers in triple-negative breast cancer. Cancer 109: 25-32, 2007.

3. Normanno N, De Luca A, Bianco C, Strizzi L, Mancino M, Maiello MR, Carotenuto A, De Feo G, Caponigro F and Salomon DS: Epidermal growth factor receptor (EGFR) signaling in cancer. Gene 366: 2-16, 2006.

4. Honeth G, Bendahl PO, Ringnér M, Saal LH, GruvbergerSaal SK, Lövgren K, Grabau D, Fernö M, Borg A and Hegardt C: The $\mathrm{CD} 44^{+} / \mathrm{CD} 24^{-}$phenotype is enriched in basal-like breast tumors. Breast Cancer Res 10: R53, 2008.

5. Kim S, Han J, Kim JS, Kim JH, Choe JH, Yang JH, Nam SJ and Lee JE: Silibinin suppresses EGFR ligand-induced CD44 expression through inhibition of EGFR activity in breast cancer cells. Anticancer Res 31: 3767-3773, 2011.

6. Gotte M and Yip GW: Heparanase, hyaluronan, and CD44 in cancers: a breast carcinoma perspective. Cancer Res 66: 10233-10237, 2006.

7. Naor D, Sionov RV and Ish-Shalom D: CD44: structure, function, and association with the malignant process. Adv Cancer Res 71: 241-319, 1997. 
8. Karihtala P, Soini Y, Auvinen P, Tammi R, Tammi M and Kosma VM: Hyaluronan in breast cancer: correlations with nitric oxide synthases and tyrosine nitrosylation. J Histochem Cytochem 55: 1191-1198, 2007.

9. Naor D, Nedvetzki S, Golan I, Melnik L and Faitelson Y: CD44 in cancer. Crit Rev Clin Lab Sci 39: 527-579, 2002.

10. Turley EA, Noble PW and Bourguignon LY: Signaling properties of hyaluronan receptors. J Biol Chem 277: 4589-4592, 2002.

11. Bourguignon LY: CD44-mediated oncogenic signaling and cytoskeleton activation during mammary tumor progression. $J$ Mammary Gland Biol Neoplasia 6: 287-297, 2001.

12. Tölg C, Hofmann M, Herrlich P and Ponta H: Splicing choice from ten variant exons establishes CD44 variability. Nucleic Acids Res 21: 1225-1229, 1993

13. Ouhtit A, Abd Elmageed ZY, Abdraboh ME, Lioe TF and Raj MH: In vivo evidence for the role of CD44s in promoting breast cancer metastasis to the liver. Am J Pathol 171: 2033-2039, 2007.

14. Bourguignon LY, Gunja-Smith Z, Iida N, Zhu HB, Young LJ, Muller WJ and Cardiff RD: CD44 $\mathrm{v}_{3,8-10}$ is involved in cytoskeleton-mediated tumor cell migration and matrix metalloproteinase (MMP-9) association in metastatic breast cancer cells. J Cell Physiol 176: 206-215, 1998.

15. Takada Y, Murakami A and Aggarwal BB: Zerumbone abolishes $N F-\kappa B$ and $I \kappa B \alpha$ kinase activation leading to suppression of antiapoptotic and metastatic gene expression, upregulation of apoptosis, and downregulation of invasion. Oncogene 24 6957-6969, 2005.

16. Murakami A and Ohigashi $\mathrm{H}$ : Cancer-preventive anti-oxidants that attenuate free radical generation by inflammatory cells. Biol Chem 387: 387-392, 2006.

17. Murakami A, Takahashi D, Kinoshita T, Koshimizu K, Kim HW, Yoshihiro A, Nakamura Y, Jiwajinda S, Terao J and Ohigashi H: Zerumbone, a Southeast Asian ginger sesquiterpene, markedly suppresses free radical generation, proinflammatory protein production, and cancer cell proliferation accompanied by apoptosis: the $\alpha, \beta$-unsaturated carbonyl group is a prerequisite. Carcinogenesis 23: 795-802, 2002.

18. Sung B, Jhurani S, Ahn KS, Mastuo Y, Yi T, Guha S, Liu M and Aggarwal BB: Zerumbone down-regulates chemokine receptor CXCR4 expression leading to inhibition of CXCL12-induced invasion of breast and pancreatic tumor cells. Cancer Res 68: 8938-8944, 2008.

19. Normanno N, Bianco C, Strizzi L, Mancino M, Maiello MR, De Luca A, Caponigro F and Salomon DS: The ErbB receptors and their ligands in cancer: an overview. Curr Drug Targets 6: 243-257, 2005.

20. Normanno N, Bianco C, De Luca A, Maiello MR and Salomon DS: Target-based agents against ErbB receptors and their ligands: a novel approach to cancer treatment. Endocr Relat Cancer 10: 1-21, 2003
21. Lurje $\mathrm{G}$ and Lenz HJ: EGFR signaling and drug discovery. Oncology 77: 400-410, 2009.

22. Eccles SA: The epidermal growth factor receptor/Erb-B/HER family in normal and malignant breast biology. Int J Dev Biol 55: 685-696, 2011

23. Schulze WX, Deng L and Mann M: Phosphotyrosine interactome of the ErbB-receptor kinase family. Mol Syst Biol 1: 2005.0008, 2005.

24. Zhang M, Singh RK, Wang MH, Wells A and Siegal GP: Epidermal growth factor modulates cell attachment to hyaluronic acid by the cell surface glycoprotein CD44. Clin Exp Metastasis 14: 268-276, 1996.

25. Zhang M, Wang MH, Singh RK, Wells A and Siegal GP Epidermal growth factor induces CD44 gene expression through a novel regulatory element in mouse fibroblasts. J Biol Chem 272: 14139-14146, 1997.

26. Martin TA, Harrison G, Mansel RE and Jiang WG: The role of the CD44/ezrin complex in cancer metastasis. Crit Rev Oncol Hematol 46: 165-186, 2003

27. Lamb RF, Hennigan RF, Turnbull K, Katsanakis KD, MacKenzie ED, Birnie GD and Ozanne BW: AP-1-mediated invasion requires increased expression of the hyaluronan receptor CD44. Mol Cell Biol 17: 963-976, 1997.

28. Xian M, Ito K, Nakazato T, Shimizu T, Chen CK, Yamato K, Murakami A, Ohigashi H, Ikeda Y and Kizaki M: Zerumbone, a bioactive sesquiterpene, induces $\mathrm{G} 2 / \mathrm{M}$ cell cycle arrest and apoptosis in leukemia cells via a Fas- and mitochondria-mediated pathway. Cancer Sci 98: 118-126, 2007.

29. Shamoto T, Matsuo Y, Shibata T, Tsuboi K, Nagasaki T, Takahashi H, Funahashi $\mathrm{H}$, Okada $\mathrm{Y}$ and Takeyama $\mathrm{H}$ : Zerumbone inhibits angiogenesis by blocking NF- $\kappa \mathrm{B}$ activity in pancreatic cancer. Pancreas 43: 396-404, 2014

30. Ali HR, Dawson SJ, Blows FM, Provenzano E, Pharoah PD and Caldas C: Cancer stem cell markers in breast cancer: pathological, clinical and prognostic significance. Breast Cancer Res 13: R118, 2011.

31. Dalerba P, Dylla SJ, Park IK, Liu R, Wang X, Cho RW, Hoey T, Gurney A, Huang EH, Simeone DM, Shelton AA, Parmiani G, Castelli $\mathrm{C}$ and Clarke MF: Phenotypic characterization of human colorectal cancer stem cells. Proc Natl Acad Sci USA 104: 10158-10163, 2007.

32. Herishanu Y, Gibellini F, Njuguna N, Hazan-Halevy I, Farooqui M, Bern S, Keyvanfar K, Lee E, Wilson W and Wiestner A: Activation of CD44, a receptor for extracellular matrix components, protects chronic lymphocytic leukemia cells from spontaneous and drug induced apoptosis through MCL-1. Leuk Lymphoma 52: 1758-1769, 2011. 